Panorama ECONómico, Volumen IV, No. 8, enero-junio, 2009, pp. 35-62

\title{
HOW CORRELATED ARE MEXICO'S SALARIES AND US OUTPUT? AN INQUIRY ON SOME US BORDER CITIES
}

\author{
Willy Walter Cortez* \\ Alejandro Islas-Camargo**
}

\begin{abstract}
RESUMEN
En este escrito abordamos la naturaleza de la integración entre el mercado laboral de ciudades mexicanas, ubicadas en la frontera norte, con la economía de los Estados Unidos de América. También indagamos sobre los cambios que se han presentado en la relación a lo largo del tiempo. Al utilizar el filtro HodrickPrescott se puede establecer el comportamiento de corto y largo plazos de las tasas salariales, en las cuatro ciudades mexicanas más grandes de la frontera norte. Encontramos que hubo un cambio en la relación entre los componentes cíclicos del ingreso laboral en México con el producto de los Estados Unidos de América. Asimismo, se observó alguna evidencia de convergencia en el crecimiento de los ingresos laborales en la frontera norte de México.

Palabras clave: Ingreso laboral, integración del mercado laboral, frontera México-EUA, filtro Hodrick-Prescott

Clasificación JEL: E3, J3, O1
\end{abstract}

* Department of Quantitative Methods, University of Guadalajara. E-mail: <wcortez@ cucea.udg.mx>. Member of Sistema Nacional de Investigadores (SNI I).

** Department of Statistics, Instituto Tecnológico Autónomo de México. E-mail: <aislas@itam.mx>. Member of Sistema Nacional de Investigadores (SNI I). 
Willy Walter Cortez/Alejandro Islas-CAMargo

\begin{abstract}
In this essay we pursue the question about the nature of integration that there is between the Mexican cities' labor market located along the northern border and the US economy. We also inquiry whether there has been any change in such a relationship over time. Using the Hodrick-Prescott filter we are able to establish the short and long term behavior of the wage rates in the four largest US Border Mexican cities. We find that there has been a change in the nature of the relationship between the cyclical components of the Mexican labor income and US output. We also find some evidence about growth convergence within northern border Mexican labor incomes.

Keywords: Labor income, labor market integration, US-Mexico border, HodrickPrescott filter

JEL classification: E3, J3, O1
\end{abstract}

\title{
1. INTRODUCTION
}

A number of studies have illustrated the extent by which trade and direct investment liberalization in Mexico fostered some economic sectors while restricted the growth of others. This process of industrial restructuring has implied the relative growth of some Mexican regions and the decline of others. ${ }^{1}$ The regional adjustments of production have also implied adjustments in their labor markets. Hanson (2003), for instance, in a study about the Mexican labor market, has pointed out the differentiated impact that economic liberalization is having upon regional labor markets; in particular, trade and investment liberalization seem to have accentuated and even increased existing differences across regional wage rates. In particular, regions most exposed to trade and overseas direct investment obtained wage gains. According to these

\footnotetext{
${ }^{1}$ See, for instance, Katz (1998) and Aguayo and Salas (2002).
} 
findings, skilled workers living in cities located near the US border were the most benefited (Meza, 2002).

In effect, since the mid-eighties Mexico began a process of economic liberalization that included, among other measures, trade and investment liberalization, elimination of price controls and changes in labor market institutions. Among all these measures, investment liberalization has been a key pillar of the new economic strategy. The government has actively sought to attract Foreign Direct Investment (FDI) through reforms to its Foreign Investment Law (FIL) in 1989 and 1993. These reforms allowed a significant reduction in the range of activities reserved for the State or Mexican citizens. Amendments to the 1993 FIL made in 1995, 1996, 1998, 1999 and 2000 accelerated the participation of FDI in Mexican economic activity (Pacheco-Lopez, 2004). As a consequence of these changes in the FIL, there was a significant increase in FDI throughout the nineties: it went from an annual average of US 6.1 billion during 1990-1995 to US 12.9 billion during 1996-2000 to US \$17.7 billion during 2000-2004 (ECLAC, 2004). ${ }^{2}$

Máttar et al. (2002) argue that FDI in Mexico has been increasingly concentrated in manufactures -for it went from 49 percent during 1981-1993 to approximately 63 percent during 1994-2000-, and has been directed mainly to maquiladora plants. They further note that FDI has been directed to highly concentrated industries, with strong multinationals' presence and that the large majority of these enterprises are of US origin. ${ }^{3}$ In fact, impressive growth of Mexican exports is mainly explained by the growth of these foreign firms' exports.

Recent studies about the Mexican labor market have argued that Mexico's economic liberalization has had a differentiated impact upon its regional labor markets. Trade and investment liberalization in particular seem to have accentuated and even increased existing wage differences across regions

22001 was a peculiar year since the total amount of FDI that came to Mexico was US billion 27.6. This amount includes the purchase of the largest Mexican commercial bank by Citicorp Group.

${ }^{3}$ It went up from about 60 percent during 1982-1993 to around 86 percent by the end of 2000 . 
Willy Walter Cortez/Alejandro Islas-CAmargo

(Hanson, 2003). Hanson further argues that regions most exposed to trade and overseas direct investment obtained wage gains. Hence, despite the fact that in recent years the growth rate of new maquiladora plants has been larger in non-border regions, a distinguishing feature of Mexico's northern border region is that it hosts about 80 percent of these plants. The economic dependence of this particular region to the behavior of the maquiladora plants is therefore indubitable. To the extent that maquiladora plants' behavior depend upon existing conditions on the US economy, it could be argued that the economic fate of the region is closely linked to the latter's performance. This explains why some studies have found some evidence of integration between the Mexican and the US labor markets.

Robertson (2000), for instance, argues that there exists a fixed gap between US and Mexico's wage rates. A wage shock in US would induce a temporary change in the wage gap which, in turn, would cause Mexican workers to migrate to the US. The later process would stop when, after an adjustment period, the initial wage differential is restored. He also finds that (labor market) integration is stronger between Mexican cities located along the US border and the US economy than between other Mexican cities and the US economy. ${ }^{4}$

In this essay we pursue the question about the nature of integration that there is between the Mexican cities' labor market located along the northern border and the US economy. In particular, we are interested in measuring the degree by which Mexican labor incomes are affected by the performance of US output. We also inquiry whether there has been any change in such a relationship after 1995. That year represents a turning point for the Mexican economy in several respects. First, Mexico's central bank adopted a flexible exchange rate system. Second, NAFTA was in its first year of being implemented. Third, it began Mexico's financial crisis with strong effects on its labor market and output.

To the extent that each of the Mexican border cities exhibit significant differences regarding population size, distance to a major US city, number and

\footnotetext{
${ }^{4}$ Both, Robertson (2000) and Hanson (2003) argue that even though both Mexico's and USA's labor markets are integrated, there is not much evidence in favor of convergence.
} 
type of maquiladora plants and infrastructure, one would expect that the type and degree of integration to the US economy in each case would be different.

There are two key characteristics of this research. First, unlike previous studies about USA's and Mexico's labor market integration we use time series techniques to measure the degree and type of integration between both economies. In particular, we decompose the behavior of labor income into its short -and long- term components. Second, to measure the degree of interdependence between Mexican labor income and the US economy we consider the cross correlations between the US output and the cyclical component for each of the four (US border) Mexican cities.

The paper is organized as follows. Section 2, builds the case for expecting that Mexican labor incomes are dependent on US business cycles. In particular, the role that FDI plays upon domestic labor market outcomes. Section 3 submits the basic ideas of the Hodrick-Prescott (HP) filter, whereas section 4 discusses the data used for the empirical analysis. Section 5 shows the main results, while section 6 concludes.

\section{FDI AND ITS IMPACT ON DOMESTIC LABOR MARKET}

Up until the early eighties the main recipients of FDI were developed economies with a large domestic market. Multinational firms (MNEs) engaged in this type of activities as a way to overcome high tariff barriers or high transport costs which restrained their participation in those (external) markets. This type of investment has been called horizontal FDI because the MNE moved the entire

production chain to the host country (Hanson, et al., 2001). However, this strategy began to change when MNEs started to see less developed economies as potential recipients of their investment flows. The MNEs began to consider other variables that would help them in their international expansion processes.

Key among these new variables was factor price differences across countries. In fact, to the extent that MNEs could lower their production costs by moving part of their production process to less developed countries (or 
LDC's) - particularly, processes that were labor intensive- the latter became very attractive to these firms. Unlike horizontal FDI, the main purpose of this later type of FDI is to use LDC's infrastructure as an export platform. To the extent that only part of the production chain has been moved to the host country, this investment is called vertical FDI.

Less developed countries, on the other hand, saw FDI as a means to accelerate their economic growth by bringing foreign technology. To attract FDI, these countries engaged in a number of domestic reforms that involved not only their foreign investment legislations but also their labor market regulations among other measures. Hanson et al. (2001), illustrate the degree to which MNEs took advantages of these "incentives" to become the more dynamic type of FDI. The use of FDI by MNEs as a means to overcome high transportation costs or high tariff barriers or as a means to take advantage of cost differences is important to determine if FDI produces horizontal integration or vertical production networks. We argue that the type of FDI (horizontal or vertical) has important implications for the type of economic integration that might arise between the MNEs' home economy and that of the subsidiary's.

We already noted that Máttar et al. (2002) argue that a key feature of FDI flows to Mexico is that they have been used to strengthen the international competitive position of the MNEs, i.e., they have been used as an export platform. As such, the volume of production of these subsidiary plants depends on demand conditions prevailing in the markets to which production is directed. If either the US economy or the international economy, or both, is facing a demand expansion, then Mexican subsidiary plants would increase their volume of production. Higher production is met with an increase in labor demand. The latter would in turn induce higher labor income, ceteris paribus. Therefore, an increase in Mexican labor income should follow an expansion in US output or of the international economy with a lag which -up to now-is unknown. ${ }^{5}$

\footnotetext{
${ }^{5}$ Key to this result is that the labor supply curve remains constant. For if there is a strong migration from other Mexican states to these border cities then labor income could fall even when labor demand is rising.
} 
However, a positive correlation between US output and Mexican labor incomes is not the only possible outcome. As a matter of fact, if Mexican subsidiary plants produce goods that are substitutes of the goods that are enjoying a expansion, then a rise in US output would induce a decline in the Mexican subsidiaries' production. The later, in turn, should induce a decline in labor demand which would cause a decline in Mexican labor income. There are two events that might explain a negative correlation between US output and Mexican wages. First, the expansion of subsidiaries' production could induce a large inflow of labor into these border cities that could have the opposite effect, i.e., it can cause a decline in wage rates rather than an increase. Second, Mexican subsidiaries supply products to international markets which are not positively correlated with the US economy.

Historically, Mexico has been one of the main FDI recipients within Latin America (LA) and the Caribbean. ${ }^{6}$ In effect, during 1990-1995 Mexico received about a third of total FDI coming to LA and Caribbean. During 1996-2000, the percentage declined significantly to about $18 \%$ even though the annual average flow of FDI to Mexico almost doubled in US dollars. During the first four years of the new century, the average percentage returned to its historical level i.e., $32 \%$.

With regards to the distribution of FDI within Mexican regions, the data indicates that during 1994-2002 a fourth of total FDI was directed to all six US-Border States. This percentage diminishes about 10 points when we exclude Nuevo Leon ${ }^{7}$ and declines even further if we consider only Baja California, Chihuahua and Tamaulipas, to about 14.2 percent on average. ${ }^{8}$ It is evident then that the pattern of FDI differs if we consider Nuevo Leon as part of the

\footnotetext{
6 The other is Brazil.

7 The exclusion of Nuevo Leon is done because it actually shares a small border region with the United States which is not a maquiladora center. Instead, it is an industrial state whose capital, Monterrey, is the third largest city in Mexico.

8 To the extent that Tijuana, Ciudad Juarez and Matamoros (located in Baja California, Chihuahua and Tamaulipas, respectively) are the oldest and the most important maquiladora centers, we wanted to isolate the percentage of FDI that was directed to this particular region.
} 
border region or not. In particular, 1997, 1998 and 2000 represent years in which FDI in Nuevo Leon followed a different trend than the rest of the Border States. In 1997, for example, Nuevo Leon experienced a large inflow of FDI, while the rest of Border States suffered a sharp decline. In 1998, the trend was reversed. Finally, in 2000 the main maquiladora states experienced a dramatic fall in FDI, while Nuevo Leon enjoyed an important inflow of FDI. The different behavior experienced by the inflow of FDI to Nuevo Leon and to the rest of border States suggests that the downturn of US economic activity is first felt in the main maquiladora centers than in the rest of the country.

Since the mid 1980s the northern border region has been losing its attractiveness as a maquiladora center. In effect, its share in total value added, number of establishments, employment, has declined steadily. For example, its percentage in overall value added declined from about $93 \%$ by the mid eighties to about $72 \%$ by 2000 . The graph below shows the percentage of value added (VA), labor income (SSP) and profits (GAN) generated by maquiladora plants located along the northern border with respect to the total plants in Mexico. It can be seen that the declining trend in all three indicators began sometime after mid 80s.

There has been some debate about the causes of this change on the distribution of maquiladora plants. Graph 1 shows that the fall in profits has been higher than the fall in labor income. This indicates that labor is taking a larger percentage of total value added in the northern border region, thus affecting the margin of profits. In other words, since the mid 80s labor costs in northern border cities are becoming more expensive. To the extent that MNEs are always looking for regions with costs advantages, the latter started to move to non-border regions.

The evolution of Mexico's in-bond industry shows that it has gone through different phases. Between 1987-1992 the number of establishments grew at an average annual rate of 13\% whereas during the period 1992-1994 it stagnated. In 1995 the industry began a new phase of expansion with an average annual growth rate of $9.7 \%$ which lasted until 2000. In 2001 a new recessive period began in the industry. 
How Correlated are Mexico’s salaries and US output? An InQuiry on some US border cities

\section{GraPh 1}

\section{Percentage of Maquiladora Plants in Border States}

Source: INEGI, Estadísticas de la Industria Maquiladora de exportación.

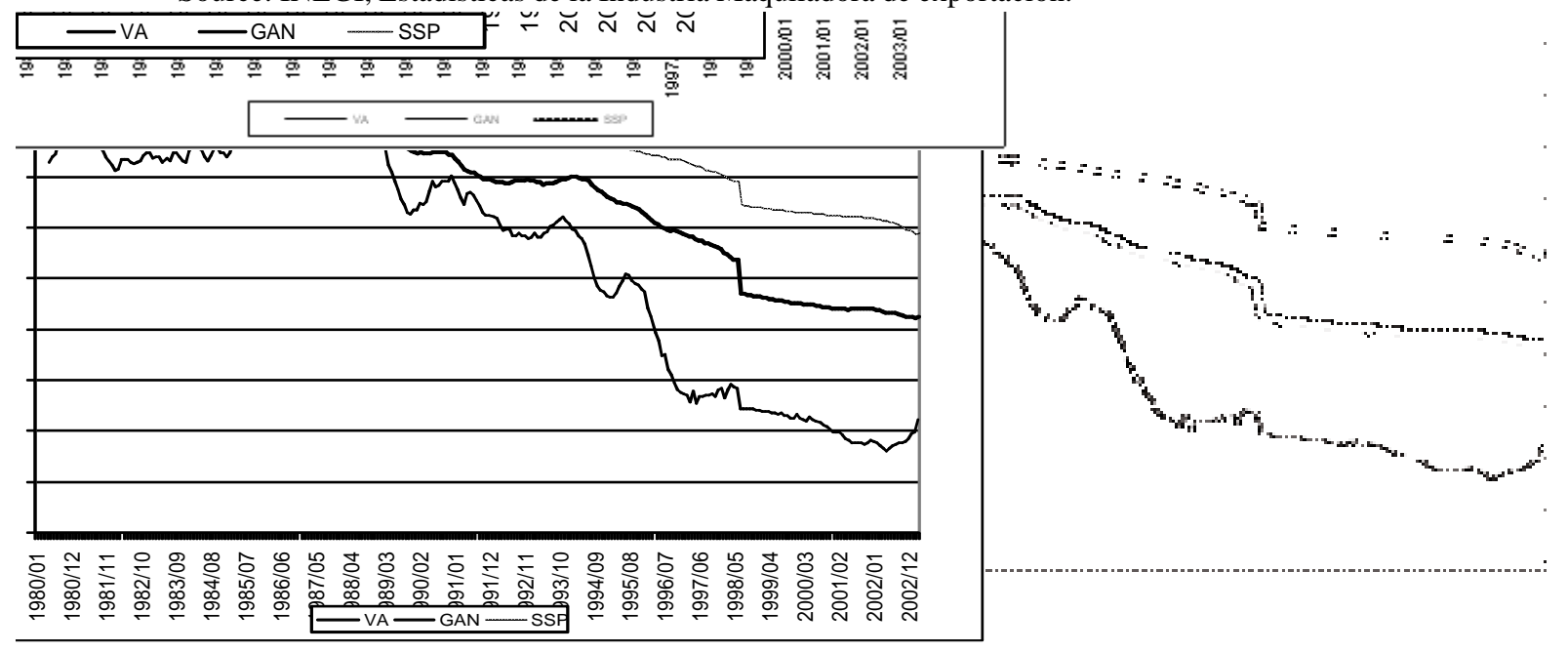

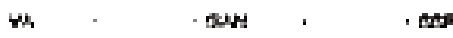


1995 represents a turning point in Mexico's economy for several reasons. First, Mexico faced an economic crisis of major proportions. Second, as a consequence of the latter, Mexico's liberalized its exchange rate market to allow its domestic currency to float freely. Third, the trade agreement between United States, Canada and Mexico was in its first year of implementation. These last two points are used to argue that there were major changes in the economic environment so that it modified the behavior of several economic variables. In particular, the nature of the relationship between Mexico's labor market and US output.

We now turn our attention to the behavior of the labor income in Ciudad Juarez, Tijuana, Matamoros and Nuevo Laredo, as well as the national average. Overall, labor income in these cities and the national average shows large swings during 1987-2003. In effect, from the early 1988 until the late 1994 Mexican manufacturing hourly income rates gained some of their lost purchasing power that resulted from the anti-inflationary policies the government had implemented a few years earlier. The upward trend, however, ended abruptly in 1995, when incomes plummeted as a result of the financial crisis of that year. ${ }^{9}$ In 1997 salaries began a new process of recovery which lasted until 2001 when they stopped growing. Throughout this period, these cities' salaries have shown a dissimilar performance so that their dispersion across cities varied significantly over time. ${ }^{10}$

Three other important characteristics of hourly income rates are: (i) the salary rates in these cities are above the national average. The differential declined significantly after 1996 with the exception of Tijuana; (ii) labor income fluctuations in these cities are wider than the national average; (iii) except

9 On average, wages fell by one-fifth during a period of three quarters. There were cities, however, where the decline was even more devastating. In Leon, for instance, wages fell by $31 \%$, while in Chihuahua, Merida and Tampico the decline was around 24\%. In other cities the decline was less severe as in Nuevo Laredo, Veracruz, Matamoros and Ciudad Juarez.

${ }_{10}$ Some cities have enjoyed a higher growth rate than others. For example, Chihuahua, Veracruz and Tampico are among the first group, whereas Mexico City, Nuevo Laredo, and Matamoros are among the latter. 
How correlated are MeXico’s salaries and US OUtPut? An INQUiry on some US border cities

Tijuana's hourly rates, the salary rates of Ciudad Juarez, Nuevo Laredo and Tamaulipas seem to be converging towards the national average. ${ }^{11}$

\section{THE HODRICK-PRESCOTT (HP) FILTER}

There is an extensive literature on the use of the HP filter in particular for the analysis of the business cycles. The HP filter has also been used to analyze comovements among economies (see, for instance, Cerro and Pineda, 2002). The strategy in this later case is to first decompose the series into its common trend and cycle component to later analyze the long run co-movement of the series. Throughout the paper, our working definition of business cycle fluctuations concerns properties of time series that have been filtered by the Hodrick-Prescott method, which remove low frequency movements from the data. Consider the decomposition model

$\dot{g}_{t}=g_{t}+c_{t}$

where is a slowly changing function known as the "trend component", and $c_{t}$, is the "cyclical component". In this model, the observed time series are viewed as the sum of the trend and cyclical components. There is also a seasonal component, but as our data are seasonally adjusted, this component has already been removed. If growth accounting provides estimates of the trend component with errors that were small relative to the cyclical component, computing the cyclical component would be just a matter of calculating the difference between the observed value and the growth component $\left(y_{t}-g_{t}=c_{t}\right)$. Our aim is to estimate and extract the components $g_{t}$ and $c_{t}$.

Hodrick-Prescott (1997) developed a smoothing method that is widely used among macroeconomists to obtain an estimate of the long-term trend component

${ }^{11}$ An inspection of the series shows that the wage dispersion among these cities was greater during 1987-1994 than during 1995-2003. 
of a series. The method was first used by them to analyze postwar U.S. business cycles. Technically, the Hodrick-Prescott (HP) filter is a two-sided linear filter that computes the smoothed series $g_{t}$ of $y_{t}$ by minimizing the variance of $y_{t}$ around $g_{t}$, subject to a penalty that constrains the second difference of $g_{t}$. That is, the HP filter chooses to minimize the following expression:

$$
\sum_{t=1}^{T}\left(y_{t}-g_{t}\right)^{2}+\lambda \sum_{t=1}^{T}\left(\left(g_{t+1}-g_{t}\right)-\left(g_{t}-g_{t-1}\right)\right)^{2}
$$

Where $\lambda$ is a parameter that controls the smoothness of the series, $\sigma$. The larger the $\lambda$, the smoother $\sigma$. As $\lambda$ goes to infinity, then $g_{t}$ approaches a linear trend. The HP filter has become the core of the paradigm for businesscycle estimation in short-term economic analysis at policy making institutions. The HP filter decompose a time series into two components: a long-term trend component and stationary cycle; it is a linear filter that requires previous specifications of a parameter known as $\lambda$. This parameter tunes the smoothness of the trend, and depends on the periodicity of the data and on the main period of the cycle that is of interest to the analyst. Nevertheless, the parameter does not have an intuitive interpretation for the user, and its choice is considered perhaps the main weakness of the HP filter.

For quarterly data, there is an implicit consensus in employing the value of $\lambda=1600$, originally proposed by Hodrick and Prescott based on a somewhat mystifying reasoning. Still the consensus around this value undoubtedly reflects the fact that analysts have found it useful. The consensus, however, disappears when other frequencies of observation are used. For example, for annual data, authors like Baxter and King (1999) recommend the value $\lambda=10$ because it approximates a band pass filter that removes from the cycle periodicities larger than 8 years; while Backus and Kehoe (1992), Giorno et al. (1995) or European Central Bank (2000) use the value $\lambda=100$. Concerning monthly data, Dolado et al. reasoning would lead to $\lambda=4800$, while the popular econometrics program E-views uses the default value 14400 . 
In this paper we follow a method proposed by Guerrero, Juárez and Poncela (2001) to find the appropriate value of $\lambda$ that yield consistent and more objective results. These authors suggest an alternative interpretation of Whittaker graduation that yields the graduated series as the best linear unbiased estimator of the true series. Through an index called the "index of precision share" attributable to the time series model, they developed a criteria to help reducing subjectivity when graduating a time series.

\section{LABOR INCOME AND US OUTPUT DATA}

The labor income data comes from Mexico's National Urban Employment Survey (ENEU). The surveys are quarterly and they are used by National Institute of Statistics to calculate unemployment rate in urban areas. Moreover, the surveys are directed at households. The analysis is carried out for four border cities: Tijuana, Ciudad Juarez, Nuevo Laredo, and Matamoros during 1987:1-2003:1. It is important to note that both the cities chosen and the period of study are determined mainly by data availability. ${ }^{12}$

Labor income refers to hourly income rate and is computed by dividing the monthly labor income by the total number of hours worked in a month. This indicator includes in addition to wages, other types of labor income such as payments by piece produced or fixed monthly income. We use the (quarterly) National Consumer Price Index (NCPI) to deflate nominal quantities, using June 1994 as the base year. In the case the worker had more than one job, we consider the labor earnings of the primary job to estimate his/her hourly labor income rate. Thus, our analysis is based on a worker who received an income for his/her job. We exclude those who worked less than 16 hours and more

\footnotetext{
12 ENEU was initiated systematically in 1987. At that time, it was carried out in 16 cities nationwide. Over the years the number of cities included in the survey increased steadily so that by the end of 2002 there were more than 40 cities included in it. The survey was replaced in 2004 by the Encuesta Nacional de Ocupación y Empleo (ENOE).
} 
than 68 hours during the reference week. We also excluded males and females younger than 12 and older than 75 years. The data analyzed are in naturallogarithms; thus the first difference is equal to the growth rate of the series.

To the extent that the production of in-bond plants covers demand requirements from the entire US economy and not only of the neighboring US states, we decided to use overall US output as a proxy of the US economic environment. Thus, the US business cycle is measured by the difference between the raw series and the estimated long term trend (US Gross National Product, 1994=100). ${ }^{13}$ The two most striking historical features of aggregate output are its sustained long run growth and its recurrent fluctuations around its growth path. Both growth and deviations from the growth trend often referred as business cycles are apparent in our series. Over horizons of a few years, these shorter cyclical swings can be pronounced; for example, the 1990-1991, 1994-1995 and 2000-2002 recessions are evident as substantial temporary declines in US aggregate activity. These cyclical fluctuations are, however, dwarfed in magnitude by the secular expansion of output. But just as there are cyclical swings in output, so too are there variations in the growth trend; growth in US GNP during the late 1980s was much stronger than it was during the early 1990s. Thus, changes in long run patterns of growth are an important feature of the relationship among US aggregate activity and US border Mexican cities' labor incomes.

\section{EMPIRICAL RESULTS}

As mentioned earlier, the analysis is based on the decomposition of the series into their two components: the cyclical and the trend. We begin with the cyclical components and then proceed with the long term trend.

\footnotetext{
${ }^{13}$ We take the US GNP from economagic.com with a sample period 1987:1 to 2003:1.
} 
How correlated are Mexico’s salaries and US output? An InQuiry on some US border cities

\subsection{CYCLICAL COMPONENTS}

The sample standard deviations of a series are our measure of series' variability, while the correlation of a wage series with US real GNP is our measure of a series' covariability. These measures are computed for the entire period 1987:01-2003:01, as well as for two sub-periods: 1987:01-1994:04 and 1995:012003:01. The analysis of the two sub-periods is carried out as a check of the stability of our indicators over time; that is, to test whether there are significant changes in our indicators as a result of NAFTA.

To the extent that a wage series might not be strongly associated with contemporaneous US real output but to its lead or lagged values, we present two types of analysis. First, we compute the coefficient of determination, $R^{2}$, for the regression of the cyclical component of Mexican labor income on US real output. The equation used to obtain the coefficient of determination is,

$$
c_{j t}=\beta_{0 j}+\beta_{j} G N P_{j t}+\varepsilon_{j t}
$$

where $c_{j t}$ refers to the cyclical component of the labor income of city $\mathrm{J}^{\text {th }}$ during period $\mathrm{t}$, and $G N P_{t}$ is the US real output at lag $\mathrm{i}^{\text {th }}, \varepsilon$ is the error term. We then estimate the coefficient of determination for the regression of the cyclical components of Mexican labor income on the lead and lag values of US output.

$$
c_{j t}=\beta_{0 j}+\sum_{i=-3}^{3} \beta_{j i} G N P_{t-i}+\varepsilon_{j t}
$$

The parameters $\beta_{j i}$ measures the correlation between the wages' cyclical components and US real output. The last term of equation is the error term. Like Hodrick and Prescott (1997), we consider the ratio of the explained sum of squares for this regression to the explained sum of squares for the regression when the coefficients are not constrained to be equal in the first and second sub-periods as our measure of stability, $\zeta$. The value of this ratio falls between 
zero and one, with one indicating that the best fit equation is precisely the same in the first and second sub-periods. To verify the stability of our results we then proceed to estimate the cross correlation between Mexican wages and US output.

Table 1 shows the standard deviation of each of the series under analysis as well as their respective contemporaneous correlation with the US output and Mexican output. The first two rows show the volatility of the short term fluctuation of the US and Mexican output respectively. The data indicates that the Mexican production is more volatile than the US, although such volatility declined after 1995. With regards to the cyclical behavior of Mexican labor income, the results indicate that Ciudad Juarez and Nuevo Laredo exhibit the highest degree of variability over time. However, their variability declined significantly after 1995. Matamoros and Tijuana, on the other hand, while presenting a smaller degree of volatility, it remained almost invariable during both periods.

\section{TABLE 1}

Standard Deviation and Contemporaneous Correlations

\begin{tabular}{|ll|ccc|ccc|}
\hline & & \multicolumn{3}{|c|}{ Standard Deviation (\%) } & \multicolumn{3}{c|}{ Contemporaneous Correlation } \\
& & $1987-03$ & $1987-94$ & $1995-03$ & $1987-03$ & $1987-94$ & $1995-03$ \\
\hline PNB USA & & 1.0 & 1.0 & 0.9 & & & \\
PNB Mx & & 3.5 & 4.3 & 2.5 & -0.213 & -0.482 & 0.250 \\
Tijuana & $(1)$ & 4.9 & 5.0 & 4.9 & 0.349 & 0.538 & 0.151 \\
& $(2)$ & & & & -0.201 & -0.146 & -0.318 \\
Ciudad Juarez & $(1)$ & \multirow{2}{*}{6.6} & 7.8 & 4.9 & 0.350 & 0.573 & 0.026 \\
& $(2)$ & & & & -0.179 & -0.343 & 0.167 \\
Matamoros & $(1)$ & 5.5 & 5.2 & 5.8 & -0.011 & 0.266 & -0.263 \\
& $(2)$ & & & & -0.054 & 0.005 & -0.181 \\
Nuevo Laredo & $(1)$ & 7.0 & \multirow{2}{*}{8.0} & 5.7 & -0.019 & 0.066 & -0.136 \\
& $(2)$ & & & & 0.015 & -0.024 & 0.038 \\
\hline
\end{tabular}

Notes: (1) correlation with US GNP; (2) Correlation with Mexican GNP. Source: Own estimates. 
The last three columns of table 1 present the contemporaneous correlation of the cyclical component of the Mexican variables with that of the US output. There are significant changes in the relationship between the Mexican variables and US output. First, fluctuations of Mexican output became positively correlated with fluctuations of US output after NAFTA. Second, the positive correlation that existed during the first period between wages in Tijuana and Ciudad Juarez and US output declined dramatically after NAFTA. Third, Matamoros' wages became negatively correlated to the US output after NAFTA. Fourth, there are signs that Nuevo Laredo's wage rates became inversely correlated with US output after NAFTA.

In contrast, the changes in the correlation between these cities' wage rates and Mexican output do not seem as dramatic as the ones with the US output. First, the negative correlation that there was between Tijuana's wages and Mexican output became stronger. Second, Ciudad Juarez's wage rates became positively correlated with Mexican output, although the coefficient turned out to be small. Third, fluctuations of Matamoros' wages moved from being insensitive to fluctuations of Mexican output to be slightly negatively correlated. Fourth, Nuevo Laredo's wage rates continued to be insensitive to fluctuations of Mexico's output.

In short, there was a reduction in the contemporaneous correlation between US output and hourly incomes in Tijuana and Ciudad Juarez. The nature of the correlation changed in the case of Matamoros and Nuevo Laredo. However, in the latter the magnitude of the correlation is still very small so that we cannot argue that there was an important change. To further evaluate the results presented in table 1, we estimated the correlation squared between Mexican labor income and US output and the coefficient of determination of equations (3) and (4) for each city. When lead and lag of US real output are included, the association between the latter, on the one hand, and Matamoros' and Nuevo Laredo's wage rates, on the other, increases dramatically with the $R^{2}$ increasing from 0.0002 to 0.223 and from 0.0003 to 0.156 , respectively. The association between Tijuana's wage rates and US output also increases significantly (from 0.121 to 0.406 ). However, the association between the latter and Ciudad Juarez's labor income does not improve much. 
The index of stability, $\boldsymbol{\varsigma}$, suggests that in the case of Nuevo Laredo and Tijuana the association between the cyclical components of their hourly income rates and that of US output (once we incorporate lead and lags) did not suffer significant changes after 1995. In contrast, the index suggests that there are important changes in the association between Ciudad Juarez's and Matamoros' wage rates and US output.

TABLE 2

Strength of association with US GNP $\left(R^{2}\right)$ and measure of stability $(\varsigma)$

\begin{tabular}{lccc} 
& $c_{j t}=\beta_{0 j}+\beta_{j} G N P_{j t}+\varepsilon_{j t}$ & $c_{j t}=\beta_{0 j}+\sum_{i=-3}^{3} \beta_{j t} G N P_{t-i}+\varepsilon_{j t}$ & $\varsigma$ \\
\hline & & & \\
Tijuana & 0.121 & 0.406 & 0.711 \\
Ciudad Juarez & 0.122 & 0.199 & 0.287 \\
Matamoros & 0.0002 & 0.223 & 0.346 \\
Nuevo Laredo & 0.0003 & 0.156 & 0.933 \\
\hline
\end{tabular}

Source: Own estimates.

The index of stability, $\boldsymbol{S}$, suggests that the type of association between US output and Mexican labor income have varied differently for each of the border cities. We further investigate the nature of such a relationship across cities, by an analysis of the cross correlation between the cyclical components of the same variables. Table 3-A presents the results for the 1987-1995 period, while table 3-B does the same for the after 1995 period.

Table 3-A indicates that during the 1987-1994 period labor income's cyclical component in Tijuana, Ciudad Juarez and Matamoros were positively correlated with that of the US output, while Nuevo Laredo's was negatively correlated. Table 3-B, in turn, suggests that the relationship between those variables changed drastically after 1995 when they all turned negative. That is, for Tijuana, Ciudad Juarez and Matamoros their labor income rates became counter-cyclical after 1995; while in the case of Nuevo Laredo the negative correlation remained even though after 1995 it preceded changes in US output. 
Table 3-A

Period 1987-1994

Cross Correlations with US output

\begin{tabular}{llllllllllll}
\hline & $r_{t-5}$ & $r_{t-4}$ & $r_{t-3}$ & $r_{t-2}$ & $r_{t-1}$ & $r_{t}$ & $r_{t+1}$ & $r_{t+2}$ & $r_{t+3}$ & $r_{t+4}$ & $r_{t+5}$ \\
\hline \hline GNP MEX & -0.01 & -0.18 & -0.2 & -0.25 & -0.32 & -0.48 & $-\mathbf{0 . 5 2}$ & -0.44 & -0.33 & -0.13 & 0.001 \\
Tijuana & -0.08 & 0.172 & 0.46 & 0.552 & $\mathbf{0 . 6 4 2}$ & 0.538 & 0.451 & 0.286 & 0.153 & 0.013 & 0.084 \\
C. Juarez & -0.3 & -0.01 & 0.228 & 0.405 & 0.498 & $\mathbf{0 . 5 7 3}$ & 0.534 & 0.482 & 0.351 & 0.163 & -0.04 \\
Matamoros & -0.01 & 0.152 & 0.28 & 0.366 & $\mathbf{0 . 3 6 8}$ & 0.265 & 0.159 & 0.049 & -0.09 & -0.15 & -0.16 \\
N. Laredo & $-\mathbf{0 . 6 3}$ & -0.52 & -0.44 & -0.22 & -0.08 & 0.066 & 0.182 & 0.216 & 0.224 & 0.181 & 0.201 \\
\hline \hline
\end{tabular}

Source: Own estimates.

TABLE 3-B

Period 1995-2003

\begin{tabular}{lllllllllllll}
\hline \hline & \multicolumn{10}{c}{ Cross Correlations with US output } \\
\hline \hline GNP MEX & $r_{t-5}$ & $r_{t-4}$ & $r_{t-3}$ & $r_{t-2}$ & $r_{t-1}$ & $r_{t}$ & $r_{t+1}$ & $r_{t+2}$ & $r_{t+3}$ & $r_{t+4}$ & $r_{t+5}$ \\
Tijuana & 0.126 & 0.449 & 0.388 & 0.319 & 0.242 & 0.250 & 0.255 & 0.302 & 0.194 & 0.178 & 0.031 \\
C. Juarez & .288 & 0.292 & 0.235 & 0.304 & 0.258 & 0.150 & -0.047 & -0.259 & -0.492 & -0.619 & -0.601 \\
Matamoros & .256 & 0.275 & 0.178 & 0.074 & -0.084 & -0.263 & -0.425 & -0.515 & -0.591 & -0.691 & $-\mathbf{0 . 6 1 3}$ \\
N. Laredo & .455 & 0.371 & 0.323 & 0.166 & 0.044 & -0.136 & -0.345 & -0.445 & -0.601 & -0.669 & $-\mathbf{0 . 6 9 3}$ \\
\hline \hline
\end{tabular}

Source: Own estimates. 
When looking at the cross-correlation before and after 1995 we observe a significant change between both periods. With the exception of Nuevo Laredo, hourly labor income in Tijuana, Ciudad Juarez and Matamoros became counter cyclical after 1995. Furthermore, their correlations is strongest when the US output lags four to five periods that of the wage series.

These results could be surprisingly according to international trade theory, which would predict a more pro-cyclical behavior. There are three possible explanations for this change in the relationship between these cities' labor income and the US output. The first one is that the generalized drop of real wages caused by the Mexican financial crises of December 1994 caused the change in their short run relationships. Given that the beginning of NAFTA and the financial crises almost coincided, it is difficult to differentiate their impact upon workers earnings individually.

Second, the trade agreement (NAFTA) might have induced a further specialization of these cities' productive apparatus. This specialization, in turn, could have caused by changes in the MNEs overall growth strategies in reaction to changes occurring in either the US domestic demand or in the international demand. Table 4 presents the employment distribution in these cities before and after NAFTA. It can be seen that Ciudad Juarez became more dependent on the production of Machinery, Equipment and Electronics (MMT), while its dependence on commerce declined slightly. Tijuana also presents a significant increase in the importance of the MMT, while the relative participation of the commerce sector declined by about two points. Nuevo Laredo, in turn, has also seen an increase in the relative importance of the in-bond industry as an employment source. Matamoros, on the other hand, does not present any significant change in its employment distribution.

Third, the counter-cyclical behavior of labor income can also be explained if the inflow of labor (i.e., migrants from other Mexican states) is larger than the expansion of labor demand caused by the US business cycles. In this case, we would observe a negative relation between the wage rate and the employment rate in these cities. In fact, the only city that presents a positive relationship 
How correlated are MeXico’s salaries and US output? An InQuiry on SOME US border cities

TABLE 4

Employment Distribution Before and After NAFTA (percentage)

\begin{tabular}{lcccccc}
\hline & \multicolumn{2}{c}{ MMT } & \multicolumn{2}{c}{ Commerce } & \multicolumn{2}{c}{ Total } \\
\hline & $\mathbf{8 7 - 9 4}$ & $\mathbf{9 5 - 0 3}$ & $\mathbf{8 7 - 9 4}$ & $\mathbf{9 5 - 0 3}$ & $\mathbf{8 7 - 9 4}$ & $\mathbf{9 5 - 0 3}$ \\
\hline Ciudad Juarez & 26.9 & 35.4 & 15.6 & 14.4 & 42.5 & 49.7 \\
Tijuana & 10.2 & 17.0 & 20.0 & 18.6 & 30.3 & 35.7 \\
Matamoros & 29.2 & 28.0 & 14.0 & 13.5 & 43.3 & 41.5 \\
Nuevo Laredo & 13.3 & 16.0 & 14.7 & 15.7 & 28.1 & 31.8 \\
\hline
\end{tabular}

Source: ENEU, several years.

between employment rate and wage rates is Nuevo Laredo. As is well known, Tijuana, Ciudad Juarez, Matamoros -and to a lesser extent Nuevo Laredoare cities with a strong attractor of labor.

\subsection{LONG TERM TREND}

Graph 3 shows the long term component of labor income for the four Mexican cities. One key characteristic is that there is a substantial change in these cities' long term pattern after 1995. In effect, up until 1994 each city followed an independent trajectory without much synchronization with the other cities. As already mentioned, the implementation of NAFTA coincided with the 1995 crisis that caused the dramatic fall of labor income in all cities. The long term recovery of the wage rate was felt sometime during 1998. However, this process of recovery has been accompanied by a movement towards a common trend in three cities with the exception of Matamoros.

At the outset we argued that a distinguishing feature of Mexico's pattern of development has been the uneven growth of regions in terms of production, employment, exports and labor incomes. The asymmetry in regional performance is largely explained by their different degree of exposure to trade and investment liberalization. The regional unbalance has manifested itself in a drastic 
reduction, even a reversion, of regional convergence of per capita output since the mid-eighties (Esquivel, 1999). Even though this outcome is consistent with endogenous growth theory in which increasing returns and externalities are the leading forces for non-convergence across regions, the case for regional convergence of worker's earnings should not be entirely rejected, especially when there is a high mobility of labor and capital across cities.

\section{Graph 3}

\section{Wages long-term trend component}

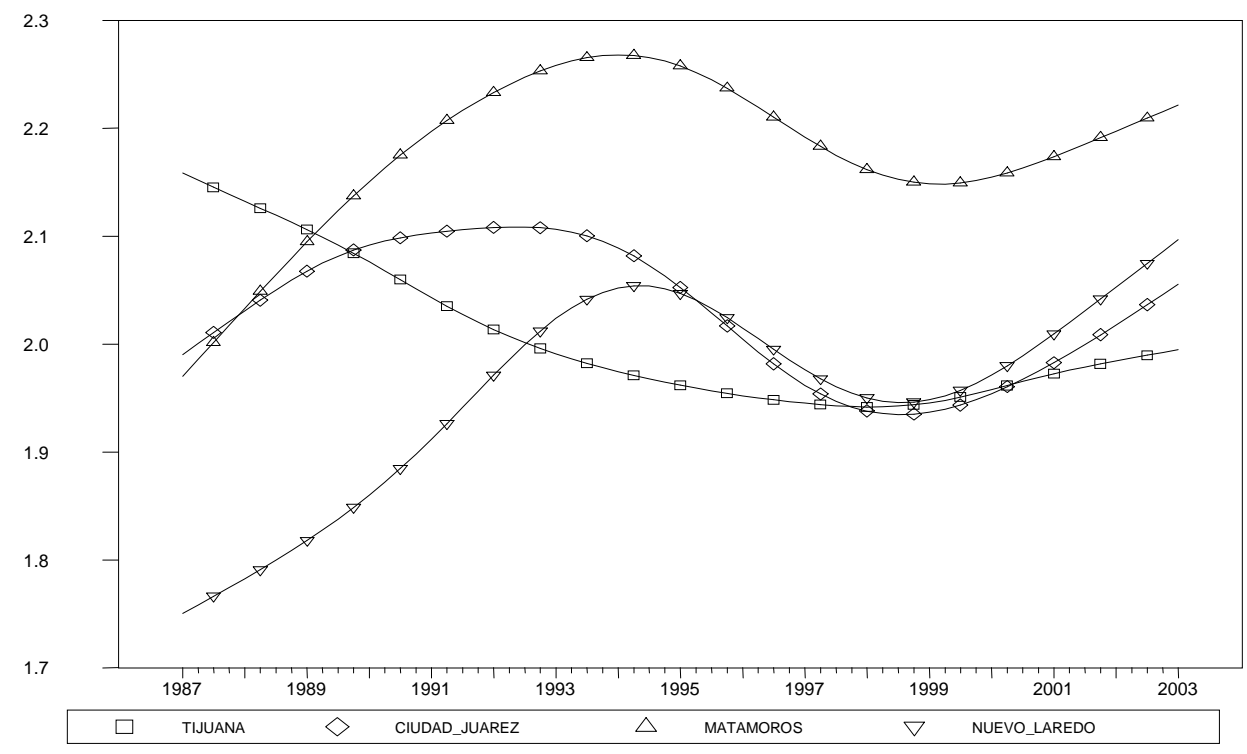

Source: Own estimates.

Under high rate of labor mobility across cities accompanied by the law of decreasing returns one would expect wages to convergence. However, wage converge would occur only if local specificity effects are weaker than labor mobility -and declining returns- effects. Furthermore, the case for wage convergence across cities is stronger when firms move to locations where factors' prices are lower. Bernard et al. (2003), for instance, found evidence 
that differences in regional labor incomes, due to their relative abundance of skilled and unskilled labor, are linked to later economic development; namely, regions with initially lower skill premium enjoy an increase in skill intensive industries which is higher than regions with initially lower skill premium.

The evidence presented in section 2 suggests that in effect there is a high degree of mobility of in-bond plants located in Mexico. Also the increasing specialization of the border regions points towards co-movements among the plants located in this particular region. Thus, over time, we should observe a process of labor income convergence across regions. ${ }^{14}$ However, the differentiated long term behavior of Matamoros deserves a particular explanation. Given the city's characteristics of its labor market institutions in particular the role that unions play in setting wages one would expect a different long term trend from the other border cities. In effect, the high and active presence of unions in Matamoros and Nuevo Laredo and the low presence of organized labor in Tijuana and Ciudad Juarez seem to have played an underestimated role. Quintero (2003), for instance, shows that there are important differences between labor unions located in Tijuana and Ciudad Juarez, on the one hand, and Matamoros and Nuevo Laredo, on the other. Unions in Matamoros and Nuevo Laredo can be identified as traditional, whose main objective is to constantly improve working conditions, including better wages. Unions in Tijuana and Ciudad Juarez are identified as subordinate or pro-management, whose main purpose is to support the maquila plants to obtain higher profits.

The existence of significant differences among organized labor has contributed to the existence of important differences in the evolution of the maquila sector across these border cities. For example, unions in Matamoros deterred the setting of unstable plants, as opposed to the number of plants that have appeared in Tijuana and Ciudad Juarez. Given the unions' strength in Matamoros, it was a harder decision for maquila plants to establish in it. Due to the differences in the number of plants established in one location or the

${ }^{14}$ Cortez (2005) in a study about wage differential across states by educational levels found that wage differences among College graduates show some signs of convergence, while the wage difference among lower educated workers is less conclusive. 
other, employment also shows similar pattern. It is more stable in Matamoros than in Tijuana and Ciudad Juarez. A third effect is the impact upon workers' turnover rate: because of their better working conditions workers are more satisfied and thus they tend to rotate significantly less in Matamoros and Nuevo Laredo than in Tijuana and Ciudad Juarez. To the extent that lower turnover rate implies a higher accumulation of experience and skill, workers' productivity may be positively affected by unions' participation.

An important observation made by Quintero (2003) is that the observed differences in wages are not due to their differences in the composition of skilled and unskilled workers but rather due to the gains obtained by their labor organizations. In fact, during 1979-2000 the distribution of workers between skilled and unskilled ones in Matamoros remained almost unchanged. The changes observed in Ciudad Juarez were more notorious. Yet, the labor income in Matamoros was higher than in Ciudad Juarez.

\section{GraPh 4}

Wages long-term growth rate

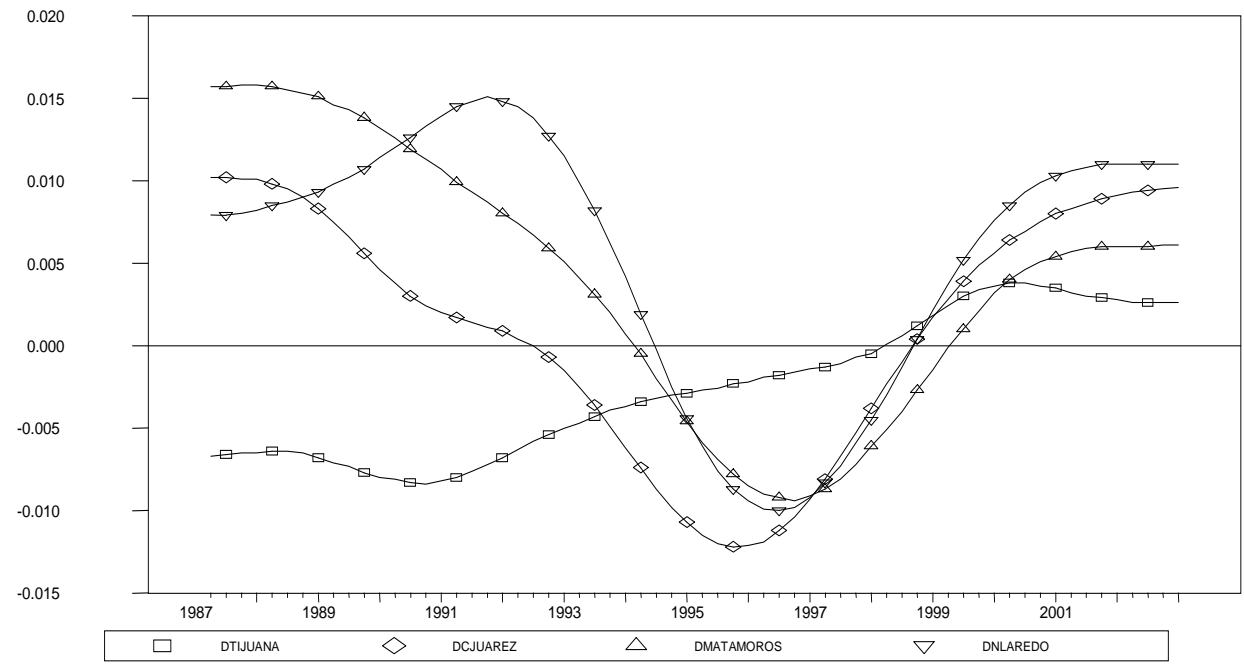

Source: Own estimates. 
The active intervention of unions in Matamoros has also induced a different mechanism of workers earning from the one existing in Tijuana and Ciudad Juarez. In Matamoros, wages are based on seniority, whereas in Tijuana and Ciudad Juarez are not. Instead, an important element in workers earnings is the bonuses, which in some companies can double the salary. ${ }^{15}$ This characteristic makes wage to be highly dependent on the companies' evolutions and less to other variables such as workers' productivity or seniority.

Finally, graph 4 shows the long term growth rates of these four cities. It clearly shows the fall in growth rates as a consequence of the 1995 crisis. However, the decline of labor income began several months earlier in Ciudad Juarez.

\section{CONCLUSIONS}

The main objectives of this essay have been three. First to establish whether there is a correlation between the cyclical components of labor income on the four largest Mexican cities along the US border and the US output. Second, to measure the degree by which incomes in Mexico's border cities are associated to US output. Third, to analyze whether there has been any change in the nature of such relationship. In particular, we tested if there were significant changes in the relationship between these series after 1995. As already mentioned, that year is considered a turning point for Mexico's economy because NAFTA came into effect, there were major economic reforms (among them the flexibilization of the exchange rate) and Mexico began a recessive period which induced a generalized decline of real labor income. Given the coincidence of these two events it is difficult to separate their effects individually.

Despite these external shocks we were able to determine the nature of the relationship between Mexican wages and US economic activity. We found that

\footnotetext{
${ }^{15}$ Bonuses can take different forms: for food, attendance, punctuality, transportation, etc.
} 
labor incomes in Tijuana and Ciudad Juarez are pro-cyclical to the US output, whereas labor income in Nuevo Laredo and Matamoros were counter-cyclical.

An interesting result of our analysis of the labor income's trend component is that after 1995 there is process towards sincronization of their growth rate. Labor incomes in these northern cities are not converging to a unique level but rather to a different steady state. The differences can be explained by their differentiated labor market institutions that do not allow convergence. Key among these institutions, we argue, labor unions are key player in determining the nature of the wages' cycles and its relationship to US output.

\section{REFERENCES}

Aguayo, F. and C. Salas-Páez (2002), "Reestructuración y dinámica del empleo en México, 1980-1998”, Región y Sociedad, Vol. XIV, Num. 25, pp. 3-62.

Backus, D.K. and P.J. Kehoe (1992), "International Evidence on the Historical Properties of Business Cycles", The American Economic Review, 82, 864-888.

Baxter, M. and R.G. King (1999), "Measuring Business Cycles: Approximate BandPass Filters for Economic Time Series", Review of Economics and Statistics 81, pp. 575-593.

Bernard, A.; S. Redding; P. Schott and H. Simpson (2003), "Relative wage variation and industry location", NBER working paper 9998, September.

Cerro, A. M. and J. Pineda (2002), "Do common cycles exist in Latin American Countries", mimeo, University of Maryland.

Cortez, W. W. (2005), "Dispersión y estabilidad de las diferencias salariales interestatales en México, 1984-2000”, Investigación Económica, Vol. LXIV, Num. 253, pp. 123-158.

Dolado, J.J., M. Sebastián, and J. Vallés (1993), "Cyclical Patterns of the Spanish Economy”, Investigación Económica, Vol. XVII, 445-473. 
How correlated are Mexico's salaries and US output? An Inquiry on SOME US border cities

Economic Commission for Latin America and Caribbean, ECLAC (2004), "Foreign Investment in Latin America and the Caribbean, 2004”, United Nations, Mexico City, Mexico.

Esquivel, G. (1999), “Convergencia Regional en México”, El Trimestre Económico, Vol. LXVI, Mexico, October-December.

European Central Bank (2000), Monthly Bulletin, October.

Giorno, CI.; P. Richardson; D. Roseveare; and P. Van den Noord (1995), "Estimating Potential Output, Output Gaps and Structural Budget Balances", OECD Economics Department Working Papers, 152.

Guerrero, V. M.; R. Juárez; and P. Poncela (2001), "Data graduation based on statistical time series methods”. Statistics \& Probability Letters, 52, 169-175.

Hanson, G.; R. J. Mataloni Jr.; and M. J. Slaughter (2001), "Expansion Strategies of US Multinational Firms", NBER Working Paper 8433, National Bureau of Economic Research, Cambridge, MA 02138, USA.

Hanson, G.; R. J. Mataloni Jr.; and M. J. Slaughter (2003), "Vertical Production Networks in Multinational Firms", National Bureau of Economic Research (NBER), Working Paper 9723, May.

Hanson, G. (2003), "What has Happened to Wages in Mexico since NAFTA? Implications for Hemispheric Free Trade", National Bureau of Economic Research (NBER), Working Paper 9563, March.

Hodrick-Prescott (1997), "Postwar U.S. Business Cycles: An empirical investigation", Journal of Money, Credit and Banking, Vol. 29, No. 1, $1-16$.

Katz, I. (1998), La apertura comercial y su impacto regional sobre la economía mexicana, Miguel Ángel Porrúa, ITAM, Mexico.

Máttar, J.; J. C. Moreno-Brid and W. Peres (2002), "Foreign Investment in Mexico after Economic Reform”, Estudios y Perspectivas \#10, Economic Commission for Latin America and the Caribbean (ECLAC), United Nations, Mexico, July.

Meza, L. (2002), "Desigualdad salarial en México en el periodo 1988-1998: un análisis regional”, Serie Documentos de Investigación, Departamento de Economía, Universidad Iberoamericana, SOO - 16, Diciembre. 
Pacheco-López, P. (2004), "Foreign Direct Investment, Exports and Imports in Mexico", Working Paper-No. 0404, Department of Economics, University of Kent.

Quintero, C. (2003), "Effects of Unions in the Mexican Maquiladoras: a comparative analisis between Matamoros and Ciudad Juarez", mimeo, El Colegio de la Frontera Norte, Dirección Regional de Matamoros.

Robertson, R. (2000), "Wage Shocks and North American Labor Market Integration", The American Economic Review, Vol. 90, Num. 4, September, pp. 742-764. 